\title{
JUSTIFYING SOURCE TAXATION IN THE Digital AGE
}

\section{Craig Elliffe*}

I chose to write on a theoretical jurisprudential topic which, ${ }^{1}$ in my view, is anchored to a practical
problem. In fact, with the rise of the digital economy, it has become the most critical functional
problem in the tax world of the 21 st century. This article attempts to establish a justification for the
taxation of income earned by highly digitalised businesses in the source or market jurisdiction. The
article explains why this theoretical question is such an important issue in international tax.

\section{INTRODUCTION}

This article is part of a special Festschrift to honour Professor John Prebble QC. It is a great pleasure through this forum to be able to thank John for the enormous contribution he has made to New Zealand taxation in general, and to tax academia in particular. I am confident that no one in New Zealand has made such a contribution to New Zealand taxation. Certainly, no New Zealand tax academic.

There are three extraordinary attributes of John that I wish to acknowledge, although I am sure he has many more. The first is his most genuine and thoughtful kindness in including me in various things when I first moved from practice to academia. He took trouble with both small and large gestures. He ensured that other New Zealanders and I were at the same table for conference dinners. He extended invitations to special conferences at the University of Ferrara in Italy or Cornell, at Ithaca in New York State.

The second of his attributes is his quite extraordinary breadth of research. Sometimes, I would be considering a new area of research upon which to plant a new flag of discovery only to find that $\mathbf{J}$ Prebble had already written two definitive articles on that topic. You will find so many references to

* Professor Craig Elliffe LLB (Hons), BCom Otago and LLM, PhD Camb, Professor of Law, University of Auckland, New Zealand, and a consultant to Chapman Tripp, barristers and solicitors. The author would like to acknowledge the assistance he has received from being New Zealand Law Foundation's International Research Fellow in 2019, Te Karahipi Rangahau à Taiao.

1 I have consulted with Fowler's Modern English Usage and ascertained at page 650 that "which" is especially important to use, rather than "that" in circumstances where one is using so-called non-restrictive clauses giving additional rather than essential information. 
John's work in academic study, tax policy statements and Supreme Court judgments. He also developed and grew new interest areas in his research. Latterly, his focus has turned to matters relating to tax jurisprudence.

Lastly, John has an extraordinary sense of humour demonstrated in his conference and events speeches. Indeed, I recall an excellent speech he gave to 2500 conference attendees in Rome in 2010 at the International Fiscal Association. It was, of course, brilliant and thought-provoking. Still, it was funny, although not as funny as the extraordinary speech he gave at the Australasian Tax Teachers conference at the Antarctic Centre in Christchurch. We have occasionally written pieces together. On these occasions, he has felt the need to refer me to Fowler's Modern English Usage. I have yet to ascertain whether this demonstrated kindness, superior knowledge or an exercise of his peculiar sense of humour (several paragraphs in a note he wrote to me on the use of scare quotes spring to mind).

Let us start with a little historical background and context to the significant question of whether taxation of income sourced in a jurisdiction can be justified. When countries decide that they will continue to operate based on worldwide residence-based taxation and to tax non-residents on income sourced in their jurisdiction, then double taxation must arise. A resident of one country earning income in another jurisdiction will be legitimately subject to tax twice: first, by the source jurisdiction where the income is earned, and secondly, by the country in which they are resident. Double taxation agreements are bilateral instruments entered into between countries that allocate taxing rights to reduce double taxation. ${ }^{2}$ The standard methods of reducing double taxation are to either eliminate or mitigate source-based taxation and to permit a credit for source-based taxation against residence taxation. Capital-importing and capital-exporting nations hammered out this international tax framework in the nervous period between the first and second world wars. The history of these negotiations suggests that this international tax framework was a negotiated compromise that was less principle-based than one might assume. ${ }^{3}$ The 1920 s allocation of taxing rights is, therefore, "an arbitrary compromise, albeit one that has come to be accepted by large parts of the international community". ${ }^{4}$

Another way to view this allocation of international taxing rights is to regard it as "where" we have landed in the field of international taxation. Importantly, it does not explain "why" we are here. To do that we should at least try to "justify" the principles of taxation, particularly as they relate to cross-border business. There are numerous different meanings given to the word "justify" in theology

2 Craig Elliffe International and Cross-Border Taxation in New Zealand (2nd ed, Thomson Reuters, Wellington, 2018) at chapter 34, 685 .

3 Craig Elliffe Taxing the Digital Economy: Theory, Policy and Practice (Cambridge University Press, Cambridge, 2021) at chapter 1.

4 Michael Devereux and John Vella "Are We Heading Towards a Corporate Tax System Fit for the 21st Century?" (2014) 35(4) Fiscal Studies 449. 
and law, but the most relevant for our purposes is "to show or maintain the justice or reasonableness of (an action, claim, and so on); to give a justification for; to defend as right or proper." ${ }^{5}$

When the great Klaus Vogel tackled the issue of justification for taxation he described it as "a forgotten question". ${ }^{6}$ His article focused on the broader question of justifying taxation from a jurisprudential perspective rather than specifically focusing on cross-border business. Still, many of the principles are, of course, relevant to an international tax dimension.

In the Middle Ages taxation was permitted only as an emergency measure. ${ }^{7}$ Theological scholars, such as Francisco Suarez, attributed the origin of such an impost to the moral philosophy of Thomas Aquinas. ${ }^{8}$ The permissible purposes for taxation included funding warfare and armament, living expenses of the sovereign (including any ransom from imprisonment) and the dowry for his daughters. ${ }^{9}$ Given the emergency nature of taxation, it was levied and used for a specific purpose. If this purpose went away, then Suarez stated that it needed to be refunded or applied to another legitimate purpose.

There have been a succession of philosophers, economists and political theorists who have written on this crucial topic. ${ }^{10}$ As Richard Musgrave says: ${ }^{11}$

The duty to pay taxes, or the power to tax, is among the most tangible of all links between subject and sovereign, or citizen and society. The struggle to overcome arbitrariness in taxation was one of the early objectives of constitutional government, and the setting of tax maxims provided a means of defining the status of the individual in the social compact.

5 Oxford English Dictionary (3rd ed, Oxford University Press, Oxford, 2013) definition of "justify" at 6.a.

6 Klaus Vogel "The Justification for Taxation: A Forgotten Question" (1988) 33(1) Am J Juris 19.

7 At 24 .

8 At 24 and 25 where Vogel refers to Suarez in the work Tractatus de legibus ac deo legislatore (1612) Lib V Cap 13 at 15 .

9 At 55

10 For a summary see Edwin Seligman "Progressive Taxation in Theory and Practice" (1908) 9(4) American Economic Association 1.

11 Richard Musgrave The Theory of Public Finance: A Study in Public Economy (McGraw-Hill, New York, 1959) at 61. 
Most traditional, and indeed current, theories ${ }^{12}$ for the justification of tax fall loosely into two major categories. ${ }^{13}$ These are the "benefit theory" and the "ability to pay theory". Convention views the benefit theory as supporting source taxation, whilst the ability to pay theory supports residence taxation. ${ }^{14}$

\section{WHAT ARE THE BENEFIT AND THE ABILITY TO PAY THEORIES?}

The difference between the two theories is based upon the fundamentally different worldview of public finance (that is, the relationship between revenue and expenditure). In the benefit theory, the taxpayer and government are seen as economic actors exchanging consideration with each other. In other words, an exchange of goods and services - something of value (taxation) in return for something of value (public goods and services).

In contrast, in the ability to pay theory, there is no connection between the benefits received and the payment of tax. Tax is therefore viewed as compulsory, without any relationship to the market.

Musgrave notes that both approaches have advantages and drawbacks. The benefit theory does not intuitively work in the area of distribution (or redistribution from the wealthy to those at risk or in need of support in society), although in his view, it does have "the great merit of tying the choice of public services to the preferences of the individual members of the community". ${ }^{15}$ There is also a significant disadvantage in that it is hard to establish how benefits are to be determined. Musgrave references John Stuart Mill, who described it as a relationship that was quid pro quo. ${ }^{16}$ Indeed, John Stuart Mill sharply rejected the benefit approach because of the regressive nature of the taxation if there was an equivalence between need and taxation. ${ }^{17} \mathrm{He}$ could not accept that the poor would be taxed proportionately more because of their greater need. Nowadays, we would not say that taxation

12 There are at least two other distinct theories - the sovereignty doctrine and the realistic doctrine. These are referred to in Niv Tadmore "Source Taxation of Cross-Border Intellectual Supplies - Concepts, History and Evolution into the Digital Age" (2007) 61(1) Bull Intl Taxn 1 at 2. In some respects these theories seem to be statements of attributes rather than theories in their own right. The sovereignty doctrine observes that the jurisdiction to make tax law exists only as far as sovereignty exists. The realistic doctrine has an inverse relationship to the sovereignty doctrine. It argues that since no rules of international law exist to limit a country's taxing jurisdiction and therefore the restriction is only one of practical enforcement.

13 Musgrave, above n 11, at 61. Also Tadmore, above n 12: Tadmore also makes the point that these are best expressed as two fundamental directions or groups of theories, but he also describes the distinction as too narrow because of the multiplicity of theories and their historical development.

14 Although this conventional viewpoint is not always accepted, see Devereux and Vella, above n 4, at 2.

15 Musgrave, above n 11, at 62.

16 At 61; see Musgrave's reference to the publication by John Stuart Mill Principles of Political Economy (WJ Ashley (ed), Longmans, London, 1921) at 804.

17 Musgrave, above n 11, at 804. 
is quid pro quo in the sense that the exchange between the parties was an exact supply of benefits to any one taxpayer in return for tax in any particular period. Instead, we would see the interaction between the state and the individual on a very general level.

The advantage of the ability to pay theory is that it simplifies the relationship to one of compulsion; it enables the state to determine how payments can be made to allocate expenditure, distribute and secure price-level stability and full employment. ${ }^{18}$ Furthermore, it positively reinforces the principles of progressive taxation. This principle suggests that taxpayers suffer a burden in proportion to their income which is why it is also sometimes described as the sacrifice theory. Of course, the ability to pay theory does not tell us how to distribute the tax burden or how to allocate the expenditure.

\section{A A Brief History of the Development of the Theories}

Studies on the development of tax theory illustrate some of the social, philosophical and historical changes throughout the centuries. ${ }^{19}$ Taxation originally began as an emergency measure, but later in the 17th century, taxation began to evolve from being on an extraordinary basis to a continuous levy. The general requirement of public necessity or utility began to replace taxation on a specific-purpose basis. ${ }^{20}$ German jurisprudence on public finance documented an early form of the benefit theory based on the social contract. The social contract theory was based on the benefit the state provided to an individual, not on the general "public benefit" of the tax. ${ }^{21}$

Adam Smith encapsulated both the benefit and the ability to pay theories in his first maxim of taxation: ${ }^{22}$

The subjects of every state ought to contribute towards the support of the government, as nearly as possible, in proportion to their respective abilities: that is, in proportion to the revenue which they respectively enjoy under the protection of the state. The expense of the government to the individuals of a great nation is like the expense of management to the joint tenants of a great estate, or all obliged to contribute in proportion to their respective interests in the estate.

18 Seligman, above $\mathrm{n} 10$, at 63 .

19 For a detailed analysis of the very many economists, philosophers and tax academics see Musgrave, above 11, at 61; Vogel "The Justification for Taxation: A Forgotten Question", above 7, at 19; and Klaus Vogel "Worldwide vs Source Taxation of Income - A Review and Re-evaluation of Arguments" (1988) 16(8/9) Intertax 216.

20 Vogel "The Justification for Taxation: A Forgotten Question", above n 6.

21 F Mann Steuerpolitische Ideale (1937) inVogel "The Justification for Taxation: A Forgotten Question", above $\mathrm{n} 7, \mathrm{n} 21$ and 35 .

22 Adam Smith The Wealth of Nations (E Cannan (ed), Vol 2, GP Putnam's Sons, 1904) at 310. 
In this statement, Smith identifies that everyone benefits from general public services and everyone should contribute to the cost of sustaining them (consistent with the benefit theory). In the absence of a practical assessment of what the individual benefit is, or what cost contribution is required, Adam Smith introduces the concept that taxation should be "in proportion to their respective abilities" (consistent with the ability to pay theory). ${ }^{23}$

By the 19th century, the ability to pay theory had taken a slightly more extreme form in the view of mostly German philosophers and economists. ${ }^{24}$ Described as the "sacrifice theory", it can be summarised in the words of Vocke as follows: ${ }^{25}$

There is no choice of the individual to determine a certain consideration for the sum of services rendered

to the individual by the community. In contrast, every individual with everything he is and owns belongs

to the community.

By the 20th century, the extreme nature of the sacrifice theory seemed to have morphed back into the more reasonable ability to pay concepts. ${ }^{26}$ Vogel attributes this to the development of the modern state and the fact that the sacrifice theory was no longer needed to accomplish the political goal of implementing a general progressive income tax. ${ }^{27}$

Of course, one of the essential features of the ability to pay theory is that you can link it to the residence of the taxpayer without any reference to benefits provided to them. This lack of connection between residence-based taxation and benefits is a double-edged sword. Some analysts see the administrative advantages of collecting tax from residents as well as allowing the full assessment of a person's ability to pay as superior and therefore recommend "a worldwide system of residence principle taxation". ${ }^{28}$ An alternative conclusion is that exclusive residence-based taxation is inappropriate when you end up taxing people who get no benefit or only a small benefit from their state.

23 Smith, above n 22, at 310 .

24 Such as Rau, Schmoller, Schaffle, Vocke, and Wagner, all of whom are discussed in Vogel "The Justification for Taxation: A Forgotten Question", above n 6, at 28-30.

25 Wilhelm Vocke Die Abgaben, Auflagen und die Stuer vom Standpunkt der Geschichte und der Sittlichkeit (Cotta, Germany, 1887) at 174 as cited by Vogel, above n 6, at 30.

26 Vogel in his review notes that the literature following this period nearly always lead in terms of ability to pay instead of using the sacrifice concept. Vogel "The Justification for Taxation: A Forgotten Question", above n 6 , at 31 .

27 At 36.

28 David Bradford and United States Treasury Tax Policy Staff Blueprints for Basic Tax Reform (2nd ed, Arlington, 1984), at 89-90. 


\section{B The Ability to Pay Theory and Taxing Non-Residents}

The residence-based tax enables a full determination of the taxpayer's correct worldwide income position, thus accurately permitting progressive tax. The ability to pay theory is, therefore, directly linked to worldwide income earned by the taxpayer. Elkins expresses it as follows: "the role played by residence in international taxation is a function of the normative underpinnings of home-country income taxation." ${ }^{29} \mathrm{He}$ distinguishes home country taxation (the tax imposed by a country on its residents) from host country taxation (the tax imposed by a government on foreign residents who engage in economic activity, including passive investment, within its territory). Justifying income tax by reference to the ability to pay tax can take a variety of different forms and doctrines. These include: ${ }^{30}$

(a) the utilitarian doctrine as discussed in the works of Jeremy Bentham and John Stuart Mill: taking a dollar from a wealthy individual causes less disutility than taking a dollar from a needy individual, and taking a dollar from a wealthy individual and using it for public services enhances the total happiness;

(b) Rawlsian principles: Rawls suggests that everyone has an equal moral claim to material resources and that justice permits deviation from an equal distribution of wealth only to the extent that such inequality works to the benefit of the least well-off stratum of society - so if the market distribution is unequal, then justice requires a redistribution of resources;

(c) the sacrifice theory: each person should experience the same degree of pain from paying taxes and because of the declining marginal utility of money a wealthy individual would need to pay more to have the same sacrificial experience.

The ability to measure who is in a position to contribute to the fisc is one of the significant desirable characteristics of the ability to pay theory, and it influences important government policy, such as that developed in the United States Treasury. ${ }^{31}$ Applying the ability to pay view to corporate income tax is not as sound as it might be to the taxation of individuals; it is unclear if the tax is borne by the company or the company's shareholders. If these shareholders are residents in another jurisdiction, the theory fails. ${ }^{32}$

While the ability to pay theory has proven an important justification for residence taxation (at least in many commentators' eyes), it has little or no relevance to most forms of source taxation. The ability to pay theory is not used, at least conventionally, to justify host country taxation. Other

29 David Elkins "The Myth of Corporate Tax Residence" (2017) 9 Columbia Journal of Tax Law 5 at 12.

30 At 12

31 Bradford, above n 28, at 89-90.

32 Devereux and Vella, above $\mathrm{n} 4$, at 3. 
commentators have simply recognised that "[t]he source of net income is simply irrelevant to abilityto-pay."33

Reuven Avi-Yonah playfully states that "source rules are a wonderful thing for lawyers and something that causes economists to despair." ${ }^{34} \mathrm{He}$ goes on to explain that economists would prefer a world without any source-based taxation where instead, a country simply taxes its residents. From time to time, Avi-Yonah suggests that economists have influenced the United States Treasury and zealously discussed the creation of a residence-based tax system. One such example is found in the Report on Global Electronic Commerce prepared by the United States Treasury in 1996, which discussed "source based taxation could lose its rationale and be rendered obsolete by electronic commerce. By contrast, almost all taxpayers are resident somewhere." ${ }^{35}$ Accordingly, the Report concluded: ${ }^{36}$

Therefore, United States tax policy has already recognized that as traditional source principles lose their significance, residence-based taxation can step in and take their place. This trend will be accelerated by developments in electronic commerce with principles of residence-based taxation will also play a major role.

It seems very unlikely that the world will embrace purely residence-based taxation. Avi-Yonah reinforces this viewpoint using two reasons: (1) it would lead to an overwhelming shift of revenue from the developing to the developed world; and (2) many countries, including the United States, would be reluctant to give up their right to tax foreigners on a source basis.

This second reason is highlighted by a more recent United States Treasury commentary: ${ }^{37}$

The U.S. system was developed at a time when the United States was the primary source of capital investment and dominated world markets. The global landscape has shifted considerably over the past decades, with other countries challenging the U.S. position of economic preeminence. The United States is now a net recipient of foreign investment rather than the largest source.

33 J Clifton Fleming, Robert J Peroni and Stephen E Shay "Fairness in International Taxation: The Ability-toPay Case for Taxing Worldwide Income" (2001) 5 Fla Tax Rev 299 at 311. It is recognised that the authors were talking about the actual source of net income (ie from one source rather than another) and so the quota is not quite contextual, but the principle is valid nonetheless.

34 Reuven Avi-Yonah International Tax as International Law (Cambridge University Press, Cambridge, 2007) at 38 .

35 United States Department of the Treasury Office of Tax Policy Selected Tax Policy Implications of Global Electronic Commerce (November 1996) at 23.

36 At 23.

37 Office of Tax Policy, United States Department of the Treasury Approaches to Improve the Competitiveness of the US Business Tax System for the 21st Century (20 December 2007) at 54. 
All this leads to the conclusion that the ability to pay theory is important to worldwide taxation, and so a critical part of cross-border taxation. Nevertheless, when dealing with inbound or host country taxation, it is to the benefit theory that we must look.

In addition to developments that took place in the ability to pay theory, there were further developments in the benefit theory. Musgrave has described these as "the Renaissance of the benefit approach". ${ }^{38}$ These developments focus on the idea of interpreting tax as consideration for state services, moving away from the idea of individuals receiving benefits into a more community-based approach. ${ }^{39}$

\section{The Renaissance of the Benefit Theory}

Vogel chooses to single out two compatriots who, in his eyes, have made significant advancements in the theory of justification for taxes, with a particular focus on the benefits theory. ${ }^{40}$ The first is Lorenz von Stein, a lawyer and philosopher writing at the end of the 19 th century. ${ }^{41}$ Stein argues that it is only through taxation that the community is placed in the position to provide individuals with the "economic conditions required for their development". ${ }^{42}$ This is a concept of mutual benefit or relationship, with individuals returning to the community a portion of the economic progress they have derived from the community. In other words, a state has provided the environment to allow the creation of economic value. In turn, taxation of this income returns to the state part of the increase in economic value.

The other critical 19th century author, according to Klaus Vogel, was Georg von Schanz. For students of tax, it is worthwhile pointing out that Schanz was the original author of the comprehensive concept of income. Henry Simons, when writing his famous text on personal income taxation, ${ }^{43}$ acknowledged two writers whose income concepts coincided with his own, Schanz and Robert Haig. ${ }^{44}$

Schanz was one of those people who thought residence-based taxation was unfair because of the lack of connection between residence and benefits provided by the state. On the other hand, he was also opposed to double taxation, which would occur if both the residence and source states imposed

38 Musgrave, above n 11 , at 68

39 At 68-89. See Musgrave's discussion of the work of Wicksell and Lindahl.

40 Vogel "The Justification for Taxation: A Forgotten Question", above n 6, at 33-46.

41 Lorenz von Stein Lehrbuch der Finanzwissenschaft (5th ed, Erster Theil and Zweiter Theil, Erste Abtheilung, Leipzig, 1885).

42 At 348

43 H Simons Personal Income Taxation: The Definition of Income as a Problem of Fiscal Policy (6th ed, University of Chicago Press, Chicago, 1938)

44 At 60. 
a tax on the same income. In his article, he proposed a fair and equitable distribution of tax burdens between the residence and source state, based upon a principle of taxation known as "economic allegiance". ${ }^{45}$ The four economists also adopted the term economic allegiance in the League of Nations Economic and Financial Commission 1923 Report (the 1923 Report). ${ }^{46}$ The first choice and principal recommendation of the four economics professors who wrote the 1923 Report, however, was to exempt source taxation and leave taxation exclusively at the residence level. The four economists subsequently adopted the term, initially used by Schanz, in discussing other alternatives than pure residence-based taxation.

The 1923 Report is certainly no model of clarity. As Vogel states regarding the use of the economic allegiance principle in the 1923 Report: ${ }^{47}$

Neither were the reasons for this conclusion convincing, nor was it politically acceptable ... Consequently,

the further development of tax treaty policy was taken out of the hands of economics professors and

transferred to technical experts.

What Schanz meant by economic allegiance was therefore fundamentally different from the residence-based taxation, proposed initially as the best option in the 1923 Report. Schanz suggested that both the state of residence and the state of source (where the investment was made) can legitimately claim taxation. State of source is justified on the grounds of services provided to the taxpayer. In Schanz's view, the share of taxation based on the services provided by the source state would be higher than that provided by the state of residence.

This means that where a person has business activities, or income arising in another state, then the allegiance to this source state is more important than to the state of residence. Although the state of residence should get its fair share, Schanz proposed that three-quarters of the income in question should be taxed by the state of source, with the residual one quarter taxed in the state of residence. Vogel supports this proposition and goes further, arguing that if indirect taxes already compensate the residence state for its services, then full taxation by the source state is justified. ${ }^{48}$

Consistent with the views of Schanz and Stein that the right to tax is linked in some way to the economic environment provided by the source state, is the view of American professor Arthur

45 G von Schanz "Zur Frage der Steuerpflicht" (1982) 9(2) Finanzarchiv 1 at 4.

46 Bruins and others Report on Double Taxation (Submitted to the Financial Committee, League of Nations Economic and Financial Commission, Document EFS73 F19, April 1923).

47 Vogel "Worldwide vs Source Taxation of Income", above n 19, at 220.

48 Klaus Vogel "Worldwide vs Source Taxation of Income - A Review and Re-evaluation of Arguments (Part III)" (1988) 16(11) Intertax 393 at 395. 
Harding's work on overcoming double taxation in the United States state tax environment. ${ }^{49}$ Similar to Stein, he observes that economic production is an outcome of an interactive community rather than individual contributions and that the state is important in that interaction. ${ }^{50}$

Harding suggests that the economic existence, nature and function of the state is to be found in this economic mechanism functioning within its territorial limits and contributing to the life, progress and happiness of the individual members of the group and, of necessity, of the group as a whole.

Harding then ties the state's right to tax into the benefits it provides to enable the group to undertake its coordinated task of producing utility or wealth: ${ }^{51}$

It appears that the State may tax all property, goods, labour, services and the like, which had become identified with the economic structure of the State, by incorporation into or integration with the business mechanism so defined ... the right to tax then depends upon the fact that the economic wealth is being used in the coordinated economic task of the social group; that it is producing utility or wealth or service in connection with, as a part of, and because of the economic solidarity of the social group.

Although Vogel, writing in 1988, expressed great admiration for Harding's work, he gave it less emphasis because it referred to interstate taxation not cross-border taxation and because it had been superseded by subsequent judicial decisions. ${ }^{52}$ This position requires reassessment in the light of the United States Supreme Court's decision on 21 June 2018 in South Dakota v Wayfair, Inc (Wayfair). ${ }^{53}$ This decision is discussed in Part III, A.

The 1923 Report concept of economic allegiance recognises various contributions made by the source and residence state to the production and enjoyment of income. ${ }^{54}$ In other words, the $1920 \mathrm{~s}$ compromise which provided the basis for the modern-day international tax system was comfortable with the concept of allocating taxing rights to the source jurisdiction on the basis that foreign-owned entities enjoyed the benefits provided by the source state (such as public services and the protection of property rights).

49 Arthur Harding Double Taxation of Property and Income: A Study in the Judicial Delimitation of the Conflicting Claims of Taxing Jurisdiction Advanced by the American States (Harvard University Press, Cambridge (MA), 1933).

50 At 42, cited in Vogel "Worldwide vs Source Taxation of Income", above n 19, at 221.

51 Vogel "Worldwide vs Source Taxation of Income", above n 19, at 221.

52 At 221 .

53 South Dakota v Wayfair, Inc, et al 17 US 494 (2018).

54 Bruins and others, above n 46, at 20. 
The four economists involved in preparing the 1923 Report discussed the four elements of economic allegiance, describing them as follows: $: 55$

1 The production of wealth; which means all the stages involved up until the wealth comes to fruition, by which they mean: 56

the oranges upon the trees in California are not acquired wealth until they are picked, and not even at this

stage until they are packed, and not even at that stage until they are transported to the place where demand

exists and until they are put with a consumer who can use them.

Under this heading, it can be seen that the production of wealth involves both the supply/residence side (manufacturing and production) and the demand/source side (transportation to the market where they are purchased and consumed). This is a more relevant category for business income.

2 The location of the wealth; where the wealth is situated.

Often this will be the location of the property. Relevant for passive investment income, the location of the investment capital could be in the state of source or the state of residence.

3 The possession of wealth; which means, substantially, the legal framework of society and the place where property rights are enforceable.

Under this heading, the right to enforce property rights can be in both the supply/residence side and the demand/source side, such as enforcing intellectual property rights or creditor/debtor obligations.

4 The disposition of wealth; which means the stage where the wealth has reached its final owner who can consume it, or reinvest it, but in the exercise of his will to do any of these things it resides with him, and his ability to pay taxes is apparent.

Under this heading, residence tax is most relevant as the owner consumes or disposes of the property. It could be noted that the property could well be situated in another state.

After analysing these four principles, the 1923 Report concluded that the stages of production "up to the point where wealth reaches fruition, may be shared in by different territorial authorities. ${ }^{57}$ It is acknowledged by the OECD that "this 'origin of wealth' principle has remained a primary basis for

55 At 22-23.

56 At 23 (emphasis added).

57 At 23. 
source taxation through the many committees and draft conventions prepared under the auspices of the League of Nations". 58

In a 1991 Report, the OECD recognised the right for source countries to tax income originating within their borders, including income accruing to foreigners: ${ }^{59}$

One justification for this entitlement is that the foreign-owned factors of production usually benefit from

the public services and the protection of property rights provided by the government of the host country.

A source-based tax like the corporation tax may also serve to prevent foreign investors from capturing all

of the "economic rent" which may arise when foreign capital moves in to exploit the host country's

production opportunities, e.g. its natural resources.

The line of thinking that links the justification for taxation and source taxation with the benefit theory has been present at the League of Nations and the OECD for some considerable time. In this sense, the benefit theory experienced a renaissance in the 20th century building on the work of the 19th century theorists (like Schanz) and became embedded in the current international tax framework. The so-called 1920s compromise of allocating taxing rights between source and residence countries is an integral part of the rules which form the basis of the modern international tax system and the OECD double tax model.

\section{THE BENEFIT THEORY IN THE DIGITAL AGE: DOES THE ABSENCE OF PHYSICAL PRESENCE IN A JURISDICTION NULLIFY THE SOURCE JURISDICTION'S TAXING RIGHTS?}

The 1920s compromise allocating taxing rights to the source jurisdiction only went so far. That is the nature of a compromise. These taxing rights were only available to the source state provided that the non-resident enterprise maintained a permanent establishment (usually a fixed place of business) in that state through which the enterprise's business was carried out. One of the most significant tax issues of the 21 st century has been the ability of highly digitalised businesses to carry out economic activity in the source state without establishing a physical presence or a permanent establishment. This leads us to the question of whether the source jurisdiction can continue to justify taxation when they carry out a part of their business without any physical presence in a jurisdiction.

\section{A The Wayfair Decision}

South Dakota has a retail sales tax. The problem was that it was unenforceable for remote sales made by an out-of-state vendor which had no physical presence in South Dakota. Two previous United States Supreme Court decisions had held that South Dakota (or other states) did not have the

58 OECD Working Party No 2 on Tax Analysis and Tax Statistics Taxing Profits in a Global Economy: Domestic and International Issues (OECD, 1991) at 32, discussing the numerous committee reports and founding double tax agreements that form the basis of the OECD Model Convention.

59 At $36-37$ 
jurisdiction to require a business that had no physical presence in the state to collect its sales tax. ${ }^{60}$ To try and prop up its sales tax base and raise essential revenue for state and local services, South Dakota passed legislation requiring out-of-state vendors to collect and remit sales tax "as if the seller had a physical presence in the State". ${ }^{61}$ The court in the Wayfair decision decided (by a narrow five to four majority) to override the previous decisions requiring retailers to account for sales tax when they trade remotely but deliver goods to people within the state, even when they lack a physical presence in the taxing state.

Wayfair is, therefore, an important decision that upheld the right of the South Dakota Legislature (or other states) to enact a law requiring out-of-state sellers to collect and remit sales tax when they deliver items to in-state purchases. From now on, states can require remote sellers to collect tax if the seller has a "substantial nexus" with the taxing state. There is not a great deal of clarity about what constitutes a substantial nexus and Reuven Avi Yonah has predicted that this will lead to more litigation. ${ }^{62}$ Justice Kennedy, delivering the majority judgment, cited a previous Supreme Court decision that "'such a nexus is established when the taxpayer [or collector] avails itself of the substantial privilege of carrying on business in that jurisdiction."'63 In this case, the majority considered that the "nexus is clearly sufficient based on both the economic and virtual contacts respondents have with the State." 64

The South Dakota Act applied only to sellers that deliver more than $\$ 100,000$ of goods or services into South Dakota or engage in 200 or more separate transactions for the delivery of goods and services into the state annually. Justice Kennedy concluded: ${ }^{65}$

This quantity of business could not have occurred unless the seller availed itself of the substantial privilege of carrying on business in South Dakota. And respondents are large, national companies that undoubtedly maintain an extensive virtual presence.

Avi Yonah considers that the Wayfair decision has broad implications for both the European Union and international tax. ${ }^{66} \mathrm{He}$ highlights the "eloquent" statement of rationale which allows states to require remote sellers to collect tax by reflecting that "the market jurisdiction provides the benefits

60 National Bellas Hess v Department of Revenue of [1967] 386 US 753; and Quill Corp v Cap North Dakota [1992] 504 US 298.

61 South Dakota v Wayfair, Inc, et al, above n 53, at 3.

62 Reuven Avi-Yonah "The International Implications of Wayfair" (2018) 160 Tax Notes 215

63 South Dakota v Wayfair, Inc, et al, above n 53, at 22, citing Polar Tankers, Inc v City of Valdez 557 US 1 (2009).

64 At 22.

65 At 23.

66 Avi-Yonah, above n 62. 
that are indispensable for the generation of profits by the remote sellers." ${ }^{67}$ What he was referring to was the remarkably clear statement by the Supreme Court of the benefits theory expressed by Justice Kennedy as follows: ${ }^{68}$

Wayfair offers to sell a vast selection of furnishings. Its advertising seeks to create an image of beautiful, peaceful homes, but also says that '[o]ne of the best things about buying through Wayfair is that we do not have to charge sales tax.' ... What Wayfair ignores in its subtle offer to assist in tax evasion is that creating a dream home assumes solvent state and local governments. State taxes fund the police and fire departments that protect the homes containing their customers' furniture and ensure goods are safely delivered; maintain the public roads and municipal services that allow communications with and access to customers; support the 'sound local banking institutions to support credit transactions [and] courts to ensure collection of the purchase price,' ... and help create the 'climate of consumer confidence' that facilitates sales ... According to respondents, it is unfair to stymie their tax-free solicitation of customers. But there is nothing unfair about requiring companies that avail themselves of the States' benefits to bear an equal share of the burden of tax collection.

The Supreme Court in Wayfair reversed the two previous Supreme Court judgments which had required a physical presence in order to constitute a substantial nexus. The majority made the following points about the physical presence test: ${ }^{69}$

It is not clear why a single employee or a single warehouse should create a substantial nexus while 'physical' aspects of pervasive modern technology should not.

A company with a website accessible in South Dakota may be said to have a physical presence in the state via the customers' computers. A website may leave cookies saved to the customers' hard drives, or customers may download the company's app onto their phones.

[A] company may lease data storage that is permanently, or even occasionally, located in South Dakota.

Between targeted advertising and instant access to most consumers via any internet-enabled device, 'a business may be present in a State in a meaningful way without' that presence 'being physical in the traditional sense of the term.'

A virtual showroom can show far more inventory, in far more detail, and with greater opportunities for consumers and seller interaction that might be possible for local stores.

The absence of physical presence, therefore, did not in any way constrain the Supreme Court from asserting that the substantial virtual connections to the state were sufficient to constitute a substantial nexus. The Supreme Court applied the benefit theory to recognise substantial virtual connections.

67 Avi-Yonah, above n 62.

68 South Dakota $v$ Wayfair, Inc, et al, above n 53, at 16-17.

69 At 15. 
While the context is one of state taxation, it is difficult to see any theoretical difference between interstate arrangements and cross-border taxation.

\section{$B$ Is there a Requirement that you can only Recognise the Benefits Provided to Non-Resident Businesses Where they have a Physical Presence in the Country of Source?}

In 2003, a Technical Advisory Group (TAG) of the OECD produced a report examining the settings of the treaty rules and the taxation of business profits in the context of e-commerce. ${ }^{70}$ The TAG could not reach an agreement, but clearly, some members felt that, even in the absence of any physical presence in the country of source, that country still had the right to tax business profits. This is important, because as Michael Lennard points out in his article, there was a lack of consensus in 2003 "even among a body composed almost entirely of representatives of developed countries, corporates or advisors". ${ }^{71}$ The TAG Report stated: ${ }^{72}$

[43] The members of the TAG disagreed, however, on an important related issue: i.e. whether a supplier which is not physically present in a country may be considered to be using that country's legal and economic infrastructure and, if that is the case, whether and to what extent, such use of a country's legal and economic infrastructure should be considered to be one factor which, under the supply-based view, would allow that country to claim source taxing rights on a share of the enterprise's profits.

[44] For some members, source taxation is justified in such a case because the business profits of the foreign enterprise derive partly from the enterprise's use of important locational advantages provided by that country's infrastructure which make the business operations profitable. These may include, but are not limited to means of transportation (such as roads), public safety, a legal system that ensure the protection of property rights and a financial infrastructure. ${ }^{73}$

[45] Other members, however, disagreed. For them, business profits derive from the carrying on, by the enterprise, of business activities and a country is only justified to consider that profits originate from its territory if the enterprise carries on activities thereon. They do not regard an enterprise which may have access to a country's market as necessarily "using" that country's infrastructure and, even if that were the

70 OECD Technical Advisory Group on Monitoring the Application of Existing Treaty Norms for Taxing Business Profits Are the Current Treaty Rules for Taxing Business Profits Appropriate for E-Commerce? (Centre for Tax Policy and Administration, Final Report, 2003).

71 Michael Lennard "Act of Creation: The OECD/G20 Test of 'Value Creation' as a Basis for Taxing Rights and Its Relevance to Developing Countries" (2018) 25(3) Transnat'l Corp 55 at 67.

72 OECD Technical Advisory Group, n 70, at 14

73 At 14, n 20 stating:

Thus the benefit principle, which provides a justification for rejecting exclusive residence taxation (see above) can also be put forward as a principle for determining the source of the business profits. The same reasoning has also been articulated in terms of the 'principle of economic allegiance.' 
case, they consider that such mere use of a country's general infrastructure would be too incidental to the business profit-making process to consider that a significant part of the profits are attributable to that country.

Around about the same time as the release of this report in 2003, Professor Dale Pinto considered the same question and concluded that it was not necessary for a foreign enterprise to maintain a physical presence in the country for the country of source to justify its taxing rights. He argues that benefits provided to non-resident vendors, even when they lack a physical presence in source countries, can still be considered as part of the justification for the right for the source country to tax the resultant income. ${ }^{74}$

Pinto considers, but rejects, an argument raised by Charles McLure that the benefit principle suggests that a physical presence is probably necessary to establish tax nexus. ${ }^{75}$ According to McLure, many of the services (such as police and fire protection) are relevantly provided only where a nonresident business maintains a physical presence in the source country. Pinto cites Arvid Skaar, who concludes that even if a business does not have a physical presence in the source country, it can still benefit substantially from its infrastructure and should make a contribution by way of taxation. In Skaar's view: ${ }^{76}$

A [permanent establishment] is merely a piece of evidence of economic allegiance, not the reason for source-state taxation ... It seems an enterprise which does not need to invest in immovable facilities, or other fixed places of business, may still derive considerable advantages from the community in which its income sources are located. Today, the performance of a business activity in another country, the duration of the activity and the profits arising from it, are per se significant arguments ... [that] requires all enterprises which obtain such benefits from country to render a corresponding contribution to the society, whether or not they have a permanent establishment.

\section{The Source Country Contribution to Digital Businesses}

It is possible to point to at least five major areas where the source country makes a contribution to the carrying on of digitalised business in its jurisdiction: ${ }^{77}$

1 The contribution to the business environment and economy: this includes the general business confidence, corruption and law and order, affluence and ability to consume. Often

74 Dale Pinto E-Commerce and Source-Based Income Taxation (IBFD Publications BV, Netherlands, 2003) at $22-23$.

75 Charles McLure "Source-Based Taxation and Alternatives to the Concept of Permanent Establishment" in Canadian Tax Foundation (ed) 2000 World Tax Conference Report (2000) at [6.5].

76 Arvid Skaar Permanent Establishment: Erosion of a Tax Treaty Principle (Kluwer Law and Taxation Publishers, Netherlands, 1991) at 559-560.

77 This list was compiled with the assistance of the list of benefits discussed in Pinto, above n 74, at 22-23. 
goods and services purchased by a resident in the source country are then consumed either in the production of further business activities (requiring a viable environment) or in private consumption (requiring a consumer with spending power).

2 The contribution to the technological infrastructure: this includes suitable telecommunications infrastructure, Wi-Fi and broadband, and a population with appropriate devices (computers and smartphones).

3 The contribution to the legal system: this includes providing reliance to enforce payment for transactions, uphold intellectual property rights (such as trademarks), and maintain a competitive and conducive business environment. The protection of intellectual property rights (for example, in the case of computer software) is critical to vendors of intangible products and digitalised services. The ability to deal with fraudulent and criminal behaviour is also important, as are consumer protection laws.

4 The contribution to infrastructure: modern infrastructure to allow physical delivery of goods in a timely and protected way, provision for waste disposal for packaging materials.

5 The contribution of users to the digital business: this may take many forms including the role of users and social media (designing or providing content), the contribution individuals make to the network effect (family, followers and friends), the provision of assets and services as part of the sharing economy (either physically located or physically performed in the source jurisdiction), the process of review and validation and assessment (on services or goods).

It seems clear that the benefit theory retains its credibility as a justification to tax non-residents in circumstances where the non-resident enterprise is enjoying or utilising the type of contribution made by the source state (or by economic actors - for example, users - in the source state). This is not a modern idea but appears to have been present right from the original theoretical construct in the 1920s compromise. The concept of economic allegiance, while it is admittedly indistinct, clearly encompasses an apportionment of taxing rights between states when the activities carried on by a nonresident enterprise utilise and benefit from the public services, legal and technological infrastructure provided in the source state.

While this theoretical argument might justify taxation by a source state in the context of dealing with digital business, this is only a question of justification. It does not suggest that the current international tax framework permits the taxation of digital business when there is no physical presence.

An important recent development in the OECD is the concept of value creation. This article will address what this concept is, where it has come from and how it relates to the benefit theory. 


\section{THE BENEFIT THEORY AND ITS RELATIONSHIP TO VALUE CREATION}

The European Commission (the Commission) states that "it is an internationally agreed principle that profit should be taxed where value is created". ${ }^{78}$ The Commission's statement is referenced to the OECD/G 20 Base Erosion and Profit Shifting Project (BEPS). Indeed, the OECD BEPS Project has focused on ensuring that "profits are taxed where economic activities take place and value is created." ${ }^{79} \mathrm{~A}$ strong case can be put forward to support the proposition that value creation is internationally agreed but it seems rather unclear what countries are agreeing to. The most recent pronouncements of the OECD/G-20 Inclusive Framework represents over 135 countries and repeats the concept that the BEPS Project is restoring taxation to the place where economic activities and value creation occur. ${ }^{80}$ In addition, Actions $8-10$ of the BEPS Action Plan profess to ensure that transfer pricing outcomes are aligned with "value creation". ${ }^{81}$

Value creation is also referred to in publications outside of the OECD/G 20 programme by the European Commission, ${ }^{82}$ as well as individual countries discussing reforms on taxing the digitalisation of the economy, such as the United Kingdom, ${ }^{83}$ Australia ${ }^{84}$ and New Zealand ${ }^{85}$

78 European Commission Communication from the Commission to the European Parliament and the Council (COM, Brussels, 21 March 2018) 146 at 4.

79 OECD Explanatory Statement: 2015 Final Reports (OECD/G 20 Base Erosion and Profit Shifting Project, 2015) <www.oecd.org> at 4.

80 OECD/G20 Inclusive Framework on BEPS Progress Report July 2018-May 2019 (9 June 2019) at 1; OECD Base Erosion and Profit Shifting Project: Addressing the Tax Challenges of the Digitalisation of the Economy (Public Consultation Document, 13 February-6 March 2019) at [11]; and OECD/G20 Inclusive Framework on BEPS Programme of Work to Develop a Consensus Solution to the Tax Challenges Arising from the Digitalisation of the Economy (2019) at [23] and [53].

81 OECD Aligning Transfer Pricing Outcomes with Value Creation, Actions 8-10: 2015 Final Reports (OECD/G 20 Base Erosion and Profit Shifting Project, 2015) at 3.

82 European Commission Communication from the Commission to the European Parliament and the Council, above $\mathrm{n} 78$, at 4 .

83 HM Treasury Corporate Tax and the Digital Economy: Position Paper (November 2017) at [1.1], which states that the "government believes in the principle that a multinational group's profits should be taxed in the countries in which it generates value."

84 Australian Treasury The Digital Economy and Australia's Corporate Tax System (Discussion Paper, October 2018) at 13. See the discussion at [4.1] on the current tax framework and its failure to properly capture the value to digitalised business of certain transactions.

85 New Zealand Inland Revenue Policy and Strategy Options for taxing the digital economy - A Government discussion document (June 2019) at 4. See the discussion at [2.5] on attribution of income by reference to the value generated in New Zealand compared to overseas. 


\section{A The Origin and Purpose of the Concept of Value Creation}

Several observations might be made about the concept of value creation. The first deals with its origin and purpose. It seems that the concept of value creation "emerged (out) of the blue" 86 and as "a messy, political idea" 87 rather than a thoroughly analysed guiding principle. As Professor Johanna Hey explains: ${ }^{88}$

Nowhere in all of the publications regarding the OECD/G20 BEPS initiative is it possible to find any

explanation why this should be the underlying principle of the international allocation in respect of taxing

rights.

The idea of value creation is an integral part of the BEPS programme, having its origin in preventing harmful tax competition, protecting corporate tax levels and upholding "the populist concept of taxing corporations in order to regulate their wealth and power." 89

As Michael Devereux and John Vella have pointed out, what began as "the guiding principle of the BEPS project ... quickly became widely accepted as the guiding principle for taxing corporate profit in an international setting more generally." 90

The principle of value creation seems to have captured the imagination of important policymakers and has morphed from the BEPS initiative, designed to deal with aggressive tax planning and tax avoidance, into one far more fundamental in dealing with the actual allocation of taxing rights. ${ }^{91}$

\section{B As a Concept of Principle it is Vague and Indistinct}

The second observation is that because value creation is a concept or principle it is quite vague. Value creation could be attributed to employee location, sales location, location of production capacity, location of management or the location where capital is raised. ${ }^{92}$ These numerous factors

86 Johanna Hey "Taxation Where Value Is Created" (2018) 72(4/5) BIT; and OECD/G20 Base Erosion and Profit Shifting Initiative [2018] BIT 203 at 205.

87 Susan Morse "Value Creation: A Standard in Search of a Process" (2018) BIT 196 at 197.

88 Hey, above n 86, at 203.

89 Morse, above n 87, at 197.

90 Michael Devereux and John Vella Value Creation as the Fundamental Principle of the International Corporate Tax System (Oxford University Centre for Business Taxation, European Tax Policy Forum Policy Paper, 2018).

91 The OECD continue to discuss and refer to the concept of value creation. For example in the OECD/G 20 Inclusive Framework on BEPS (progress report July 2019-July 2020) published by the OECD in July 2020 there is consistent and repeated discussion of the concept. See for instance the references at page 13, 19, 20 and 21 of this report, available at <www.oecd.org>.

92 Morse, above n 87, at 197. 
are necessary components of the generation of profit but may be spread over a number of countries, "making it impossible - even conceptually - to pinpoint the contribution of each specific location to the overall profit earned." 93 The only thing that seems clear, because of its BEPS and anti-avoidance background, is that no value is created where there is no real economic activity or business. Academic commentators have pointed out that this imprecision is somewhat misleading and that value creation's real problem is that: ${ }^{94}$

the new guiding principle stems from the fact that it pretends to give better answers to the issues of

allocation, while eventually turning out to be only a new variant of the source principle.

This lack of clarity has led to a suggestion from Professor Susan Morse that there is a need for a value creation dispute resolution forum. Such a forum could disclose both its procedural rules and its decisions. It would therefore make "hard" case law which would have precedential value and be both transparent and influential in determining allocations of income and deductions to different jurisdictions. ${ }^{95}$

\section{Alignment with the Benefit Theory}

The third observation is that there is a strong argument that the concept of value creation is simply a new version or name for the benefit theory. When a country makes a contribution through public services and the legal and economic environment which enable the creation of value for an enterprise, then the benefit theory justifies taxation. ${ }^{96}$

Value creation, as indicated above, might be attributed to the activities undertaken by employees, the impact of the market, and the legal, physical and technological infrastructure. These and other activities could permit market countries to claim a share of the tax base. ${ }^{97}$

The OECD recognises in the commentary on Actions 8-10 that value creation can even include "location savings", which are those cost savings attributable to operating in a particular market. ${ }^{98}$ Of course, the value will also be created in the location of production (wherever that might be for highly digitalised businesses). It is equally likely to justify the corporate taxing rights for a company's head

93 Michael Devereux and John Vella Implications of Digitalisation for International Corporate Tax Reform (Oxford University Centre for Business Taxation, Working Paper 17/07, 2017) at 9.

94 Hey, above n 86, at 205.

95 Morse, above n 87, at 198-199.

96 The articles in the Bulletin for International Taxation by Johanna Hey and Susan Morse conclude similarly.

97 Hey, above n 86, at 204.

98 OECD Aligning Transfer Pricing Outcomes with Value Creation, Actions 8-10: 2015 Final Reports, above n 81 , at $43-44$. 
office, based on the value created from capital raising or the use of intellectual property, amongst many other factors.

All of this suggests that value creation is a sufficiently broad and diverse principle to justify the allocation of taxing rights to both the country of source and of residence.

The advance that the concept of value creation brings to international taxation in highly digitalised businesses is the possibility of nexus being established without physical presence. In that sense, value creation is focused on the justification of tax and not the attribution of income.

The next stage of attributing profits to value creation is far more difficult than the principle of justification for tax. As various commentators have pointed out, attributing profits to value creation is a very difficult task, ${ }^{99}$ in fact, as difficult a task as trying to establish the correlation of profits to the benefits provided by a state. ${ }^{100}$

\section{$D$ The Relationship between Value Creation and the Existing International Tax Framework}

As discussed, the existing international tax system is based on a pragmatic compromise. This framework allocates certain kinds of income (predominantly passive income such as interest, royalties and dividends) primarily to the residence state, whilst enabling the source state to tax business income (subject to the permanent establishment threshold).

It does not seem possible to reconcile value creation with the existing international tax framework, despite the best attempts of the OECD to do so. ${ }^{101}$ The principle of value creation is a change from

99 Hey, above n 86, at 205:

Some of these problems arise from the incoherence between the theoretical foundation and the tax base to which it is applied ... Consequently, the use of public goods is neither a good justification for taxing income nor does it provide any guidance for measuring and attributing the income of an MNE to different jurisdictions. Some MNEs could make intense use of public goods but ultimately realize significant losses, such as in the shipbuilding industry.

100 Devereux and Vella, above n 93, at 6:

First, profit is likely to be a poor proxy for the benefit received. Highly profitable companies may make limited use of public services and resources, while loss making companies may place a very heavy burden on them.

These two authors also make the same point in their excellent article, Michael Devereux and John Vella "Taxing the Digitalised Economy: Targeted or System-Wide Reform?" (2018) 4 BTR 387 at 393.

101 As previously discussed, the OECD put forward the proposition that the focus of the BEPS project was to ensure that "the profits are taxed where economic activities take place and value is created": See OECD Explanatory Statement: 2015 Final Reports, above n 79. 
the 1920s compromise and therefore a replacement for that hybrid mix of residence and source taxation.

For a start, the value creation concept has nothing to do with residence taxation. Many jurisdictions impose worldwide taxation on their resident corporations (although quite a few exempt active business income). The taxation of a resident corporation on its foreign-sourced income cannot be justified under the concept of value creation. ${ }^{102}$

Secondly, value creation, as discussed above, can be attributed at least in part to the marketplace, giving a source country taxing rights purely on the grounds of its customers. According to the OECD, in the view of many countries, the concept justifies taxation of highly digitalised business models because of a misalignment between the existing nexus and profit allocation rules between the location in which profits are taxed and the location in which value is created: ${ }^{103}$

... most of the countries in this group reject the idea that a country that provides the market where foreign enterprise's goods and services are supplied on its own provides a sufficient link to create a nexus for tax purposes, regardless of the scale of these supplies. Instead, they consider that profits should continue to be taxed exclusively where the factors that produce the income are located, in accordance with longstanding principles of the existing tax system (e.g., aligning profit with value creation).

These countries are deeming value to be created only by activities on the supply side (research and development, production and marketing) and not on the demand side (purchasing the goods or services). Maartin de Wilde asks the question: ${ }^{104}$

If the demand side is relevant for creating income, why then does international tax law currently take no account of this when apportioning companies' international profits? The answer would seem to be that this is simply how things have evolved. [...] a 'product of history'.

Devereux and Vella carefully (and correctly) point out that ignoring value creation on the demand side "flies in the face of basic economic logic." ${ }^{105}$ They then go on to illustrate how value is created on the market (demand) side: ${ }^{106}$

102 Devereux and Vella "Value Creation as the Fundamental Principle of the International Corporate Tax System", above n 93, at 3.

103 OECD/G20 Inclusive Framework on BEPS Tax Challenges Arising from Digitalisation - Interim Report (2018) at 172.

104 Maartin de Wilde "Tax Jurisdiction in a Digitalizing Economy: Why 'Online Profits' are so Hard to Pin Down" (2015) 43(12) Intertax 796 at 798.

105 Devereux and Vella "Taxing the Digitalised Economy: Targeted or System-Wide Reform?", above n 100, at 394.

106 At 394 
The income being allocated among countries owes as much to the market as it owes to the various parts of a supply chain. Income depends on the price charged at the point where supply and demand meet; it simply would not have arisen in the absence of a market. It is not entirely clear why the international corporate tax system should depart from a simple and uncontroversial economic understanding of value creation.

In the 1923 Report, the economists discussed the production of wealth and gave an example that supports the same point - taxing rights can be shared between the supply and demand sides of the market: ${ }^{107}$

The oranges upon the trees in California are not acquired wealth until they are picked, and not even at this stage until they are packed, and not even at that stage until they are transported to the place where demand exists and until they are put with a consumer who can use them. These stages, up to the point where wealth reaches fruition, may be shared in by different territorial authorities.

The current international tax system does not allocate taxing rights in respect of business profits unless the permanent establishment (PE) threshold is established and the business of the foreign entity is being carried on through the PE. The 1920s compromise prevents the source state from fully taxing active business income and allocates some taxing rights to the residence state where the PE threshold is not met.

Non-resident enterprises can "do" business in a jurisdiction in many different ways, some requiring a physical presence in the jurisdiction and some not (contracts might be concluded or partly performed in the source country, which may not require actual physical presence). Most countries' domestic sourcing rules require certain activities to be carried on in the country to constitute business income. Sometimes this threshold under domestic law is quite low and vague.

Value creation, arguably, is another reiteration of the benefit theory which is challenging the 1920s compromise. Seen in this light, the OECD is correct, in its more recent documents, to describe the use of value creation as a "new taxing right". ${ }^{108}$

The OECD/G20 Inclusive Framework on BEPS has described, under the heading of "revised nexus and profit allocation rules", three new proposals to allocate more taxing rights to the jurisdiction of the consumer and/or user which they refer to as the "market jurisdictions" in situations where "value is created by business activity through (possibly remote) participation in that jurisdiction that is not recognised in the current framework for allocating profits". ${ }^{109}$

107 Bruins and others, above n 46, at 23.

108 OECD/G20 Inclusive Framework on BEPS Programme of Work to Develop a Consensus Solution to the Tax Challenges Arising from the Digitalisation of the Economy, above n 81, at 11.

109 At 11, [23]. Also known as Pillar One and referred to in the document. 
As can be seen from above, the OECD/G20 view the value creation principle as justifying the right to consider the taxation of entities deriving income from cross-border activities in the digital age (establishing a nexus) in the absence of physical presence. At the same time, the OECD/G20 recognises that the existing rules do not permit this due to the consequences of constraint arising from the 1920s compromise. The 1920s compromise framework dictates the need to describe the current proposals, using value creation as a "new" taxing right. This new compromise, the 2020 s compromise, is self-evidently possible and can be theoretically based on the concept of value creation, viewed as a development of the benefit theory.

By using the value creation principle in two different ways, the OECD have created much of the confusion. It was originally used as a core component of the BEPS 1.0 project to identify profit shifting and to bolster the transfer pricing rules, but more latterly, it has also been used as a principle for the justification and allocation of taxing rights.

\section{CONCLUSION}

Can the imposition of tax in the market or source country be justified even when the non-resident taxpayer has no physical presence in that jurisdiction? To address this question this article began by explaining both the benefit and the ability to pay theories. It is generally accepted, both from an historical and a contemporary perspective, ${ }^{110}$ that the benefit theory is an important part of the justification for source taxation. Further, this benefit theory applies also to highly digitalised businesses that may not have a physical presence in the source or market jurisdiction. There are at least five major areas where the source jurisdiction provides significant benefits to such highly digitalised businesses. ${ }^{111}$ This analysis supports, on a theoretical basis, the right for source or market jurisdictions to impose a tax on highly digitalised businesses operating without physical presence and using remote selling.

Finally, the concept of value creation is examined in order to see whether it is a new development and a clear and well understood principle upon which to justify source taxation. Despite the enthusiastic adoption of the principle by the OECD, it seems to have a more meaningful focus in the anti-avoidance context of base erosion and profit shifting than in establishing and justifying the right to taxation. Seeing whether a multinational subsidiary located in a tax haven is performing functions that create value commensurate to the profits allocated to it is meritorious from an anti-avoidance perspective, which examines true economic substance and contribution.

Despite these limitations, the proposition put forward in this article is that the concept of value creation is a further development of the benefit theory, justifying (as in showing the reason for, or

110 As it is expressly discussed by the OECD Technical Advisory Group referred to in the discussion highlighted, above $\mathrm{n} 73$.

111 See Part II, A. 
fairness of) source taxation but doing no more. In other words, if some value is generated for a nonresident enterprise in a market jurisdiction, it is because that enterprise is utilising some of the benefits provided by that source/market jurisdiction to create that value due to factors of demand rather than factors of supply. The benefits in this market jurisdiction arise because of technology infrastructure, legal systems which sustain contractual obligations and permit enforcement of debts, as well as a variety of other benefits discussed above. What seems clear is that the hard questions relating to attributing profits to activities carried on in a jurisdiction or any of the other questions relating to quantification and apportionment of such income are not answered by such a concept.

In the 1920s the allocation of taxing rights was a negotiated compromise. The 2020's compromise can justifiably settle on the right of the source jurisdiction to impose taxation due to the operation of the benefit principle. 